\title{
The Influence of Heat Input to Mechanical Properties and Microstructures of API 5L-X65 Steel Using Submerged Arc Welding Process
}

\author{
Suryana $^{1, *}$, Agus Pramono ${ }^{1}$, Iskandar $\mathrm{Muda}^{2}$, and Ade Setiawan ${ }^{1}$ \\ ${ }^{1}$ Metallurgical Engineering, Faculty of Engineering, Universitas Sultan Ageng Tirtayasa, 42435 Cilegon, Indonesia \\ ${ }^{2}$ Metallurgical Engineering, Faculty of Engineering, Universitas Jenderal Achmad Yani, 20485 Bandung, Indonesia
}

\begin{abstract}
API 5L-X65 steel is the type of high strength low alloy (HSLA) steel, widely used in the manufacture of pipe. Submerged arc welding (SAW) is widely used for the fabrication of the pipe, the extent of use submerged arc welding caused it could be done automatically and high reliability. The results of the welding process will lead to differences and changes in the microstructure in heat affected zone (HAZ) and weld metal that will affect the mechanical properties of the output, so as to obtain good welding results required the selection of welding parameters accordingly. As the use of the heat input during welding is very important influence on the mechanical properties and microstructure of the weld. The purpose of this study to determine the effect of heat input on the microstructure, hardness and toughness of welds in submerged arc welding. Welding currents used were 200, 300, 400 and 500 Ampere with a voltage were used 25, 27 and 30 Volt. The results showed that the higher heat input will result in a growing area of HAZ region width and grain size increased. Highest hardness values are the results of the weld heat input with a low of 244.69 HVN caused by the rapid cooling rate of the weld area. The highest toughness values are the results of the highest heat input that was dominated by acicular ferrite phase.
\end{abstract}

\section{Introduction}

At present, welding is one of the most widely used techniques of plumbing in piping, for example in the construction of pipe fittings, oil pipes and gas pipelines. The API 51-X65 steel is included in HSLA steel which is widely used in pipe making applications. The welded product will have good quality when the resulting weld area can provide perfect continuity between the parts connected with each part of the joint, so that the joints and the parent metal do not show any obvious difference. Therefore, there are conditions that must be met in the welding process among others, the existence of heat input.

HSLA steel is developed with special chemical composition to achieve higher mechanical properties. HSLA steels are manufactured to produce good mechanical properties and have greater corrosion resistance than conventional carbon steels. HSLA steel contains a low carbon $(0.05 \%-0.25 \% \mathrm{C})$ so that it is able to shape and weld from this steel better than mild steel and has a manganese content up to $2 \%$ [1].

The API 5L-X65 steel is included in HSLA steel standards where this steel is a type of steel that is widely applied to pipes designed specifically for subsea pipes, with the $5 \mathrm{~L}$ specification being a standard specification by the conference of manufacture and distribution of pipes channels for oil, water and gas with exceptional usage conditions. And grade X65 shows this underwater pipe has minimum allowable stress of 65,000 psi or 448 MPa which is widely used in the structure of the oil and gas platforms.

Submerged arc welding is one type of electric welding by the process of combining the welded material by heating and liquefying the parent metal and electrode by an electric are located between the parent metal and the electrode. Metal melt currents and arcs are covered with fluid granules over the welded area. Submerged arc welding does not require pressure and filler metal is mechanically supplied continuously into a metal arc formed between the tip of electrode filler and the parent metal deposited by the flux [2].

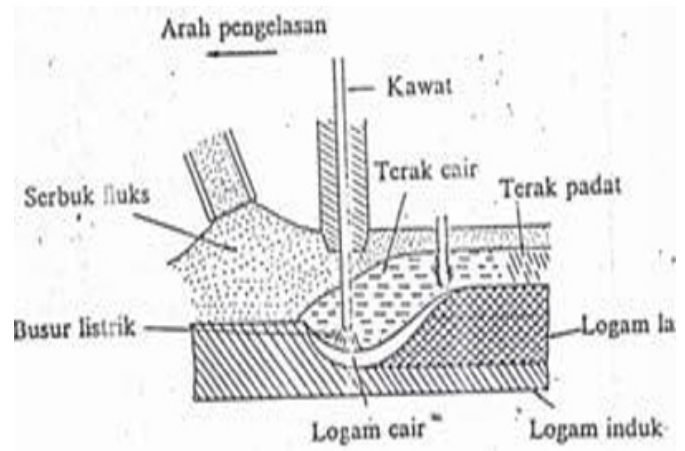

Fig. 1. Submerged Arc Welding Process [2].

Corresponding author: suryana@untirta.ac.id 
In arc welding, the source of energy come from electricity that converted to heat energy. This heat energy is actually the results of collaboration of current, voltage and speed of welding. The third parameter is the speed of welding also affect the welding energy because the heating process is not still but moving with a certain speed. The relationship between the three parameters that produce welding energy is often called heat input that can be written in the following equation [3]:

$$
H I=f_{i} \frac{60 E I}{v}
$$

where:

$\mathrm{HI}=$ Heat Input (joule/mm)

$\mathrm{f}_{\mathrm{i}}=$ Weld Heat Efficiency $(\mathrm{SAW} \approx 0.9-1.0)$

$\mathrm{E}=$ Arc Voltage (volt)

$\mathrm{I}=$ Welding Current (ampere)

$\mathrm{v}=$ Welding speed $(\mathrm{mm} / \mathrm{min})$

During welding, the welded metal and heat affected zone (HAZ) will undergo a series of thermal cycles, is heating to maximum temperature followed by cooling to room temperature. The thermal cycle affects the microstructure of the welding metal and HAZ, in which the weld metal will undergo a series of phase transformations during the cooling process, is from molten metal turns to ferrite- $\delta$ then austenite- $\gamma$ and ultimately becomes ferrite- $\alpha$ or dependent bainite at its cooling speed.

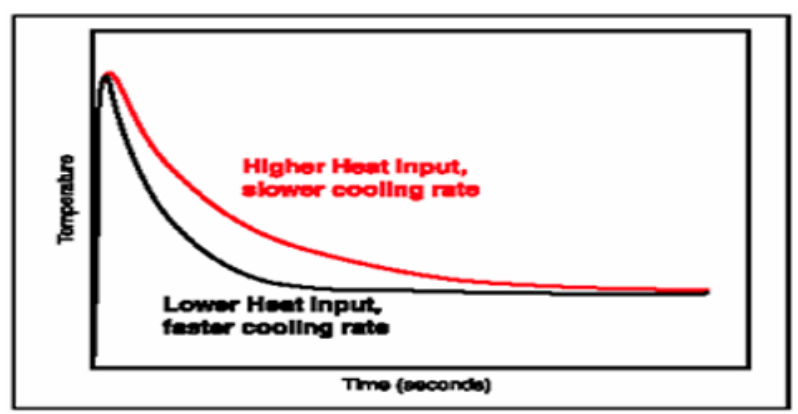

Fig. 2. Thermal Cycle during Welding [4].

According to Abson and Pargeter [5], the microstructure of welding metal comprises combinations of two or more of the following phases arranged according to their forming temperatures:

1. Fine grain boundaries are formed between the temperature of $1000-650^{\circ} \mathrm{C}$ along the austenite grain boundary.

2. Ferrite widmanstatten is formed between the temperature $750-650^{\circ} \mathrm{C}$.

3. Ferrite acicular is formed between the temperature $650^{\circ} \mathrm{C}$.

4. Bainite is formed between the temperature 400$500^{\circ} \mathrm{C}$

5. Martensite is formed when the cooling process is very fast.

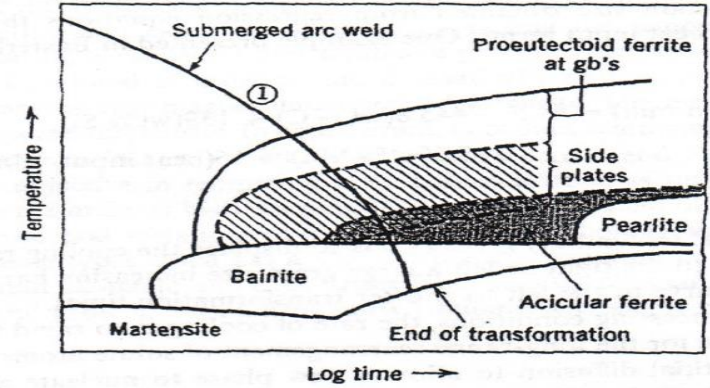

Fig. 3. CCT Diagram on SAW [3].

\section{Experimental}

Submerged arc welding process was conducted to study the influence of heat input on mechanical properties and microstructure of API 5L-X65 steel. The base metal used in the present investigation was in the form API 5L-X65 plate with sizes $150 \mathrm{~mm} \mathrm{X} 75 \mathrm{~mm} \mathrm{X} 11 \mathrm{~mm}$ and the filler was CHW-S11 solid electrode of $3.2 \mathrm{~mm}$ diameter. Table 1 show the chemical composition of the base and the filler used.

Table 1. Chemical Composition.

\begin{tabular}{|c|c|c|}
\hline Elements & $\begin{array}{c}\text { Base } \\
\text { Material } \\
\text { (API 5l X65) }\end{array}$ & $\begin{array}{c}\text { Filler } \\
\text { Material } \\
\text { (CHW-S11) }\end{array}$ \\
\hline $\mathrm{C}$ & 0.074 & 0.090 \\
\hline $\mathrm{S}$ & 0.028 & 0.010 \\
\hline $\mathrm{Ni}$ & 0.221 & - \\
\hline $\mathrm{Cu}$ & 0.160 & 0.170 \\
\hline $\mathrm{Si}$ & 0.257 & 0.150 \\
\hline V & 0.042 & - \\
\hline $\mathrm{Cr}$ & 0.106 & 1.350 \\
\hline Mn & 1.117 & 0.750 \\
\hline $\mathrm{Nb}$ & 0.054 & - \\
\hline Mo & 0.006 & 1.500 \\
\hline $\mathrm{P}$ & - & 0.012 \\
\hline
\end{tabular}


Here, double V-groove was used so that welding could be accomplished ensuring full penetration. Before welding process, all the edge of plate were thoroughly cleaned to avoid any source of contamination, that could result weld defect. Bead-on-plate submerged arc welding was performed along the centre line of plate. Submerged arc welding process was conducted by varying current and voltage i.e. 200, 300, 400 and 500 Ampere and 25, 27 and 30 Volt, respectively. While the welding speed was kept constant to obtained heat input value as independent variables.

The samples were denoted by $\mathrm{A}$ and $\mathrm{B}$ as shown in Fig. 4. Sample A was polished at various grit papers and after cloth polishing microhardness was performed perpendicularly along weld pool, HAZ region and base metal. Sample B were used for Charpy impact testing at different testing temperatures.

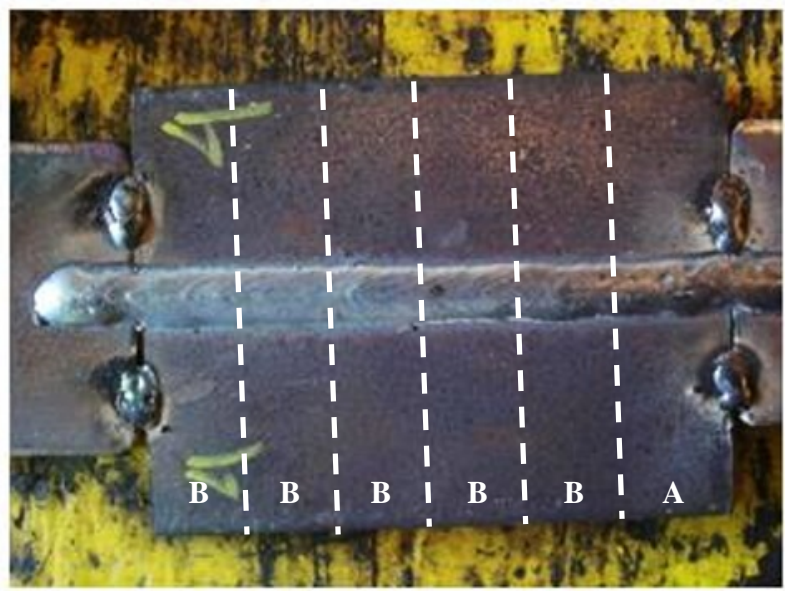

Fig. 4. Bead-on-plate Submerged Arc Welding.

In order to observe the change of microstructure that take place during welding, related to each heat input combination; specimens were machined from the weld pads. Standard polishing procedures were used for general observations of microstructure. Microstructure of different zones i.e. weld metal, HAZ, and fusion boundary under different heat input combination were viewed and captured with an optical microscope (Zeiss Axiolab) coupled with an image analysis software.

The machined specimens of different heat input condition were used measuring micro-hardness of different zones of the weldment. The 200 gf Vickers hardness testing machine was used. Charpy impact testing was used to measure toughness and ductile-brittle transition temperature. This testing was conducted at different temperature i.e. $-40^{\circ} \mathrm{C},-20^{\circ} \mathrm{C}, 0^{\circ} \mathrm{C}, 10^{\circ} \mathrm{C}$ and $27.4^{\circ} \mathrm{C}$.

\section{Results and Discussions}

\subsection{Influence of Heat Input on Microstructures}

Microstructure is a major factor in determining the mechanical properties of welded material, so this has an important role in analysing the results of welds. In this study the discussion of microstructure of the weld metal area for all variations of heat input $0.75 \mathrm{~kJ} / \mathrm{mm}$ to 2.25 $\mathrm{kJ} / \mathrm{mm}$ can be seen in Fig. 5 .

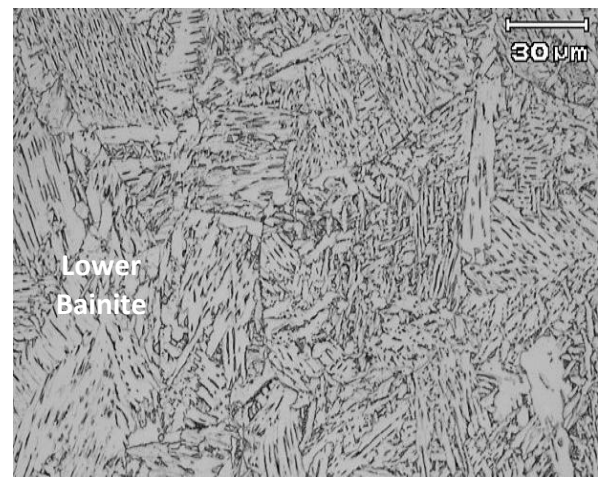

Fig. 5a. Microstructure of Weldment at $0.75 \mathrm{~kJ} / \mathrm{mm}$ of Heat Input.

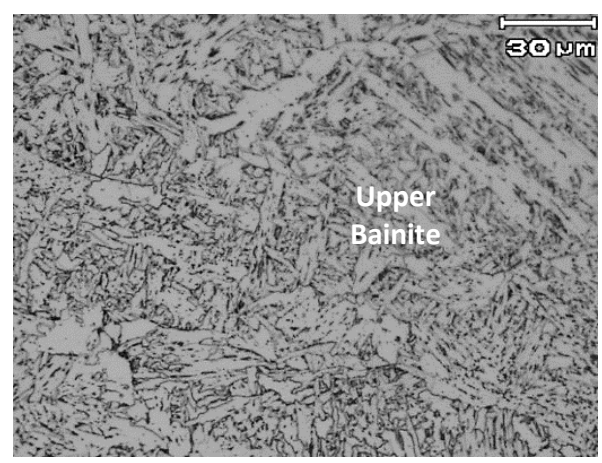

Fig. 5b. Microstructure of Weldment at $0.81 \mathrm{~kJ} / \mathrm{mm}$ of Heat Input.

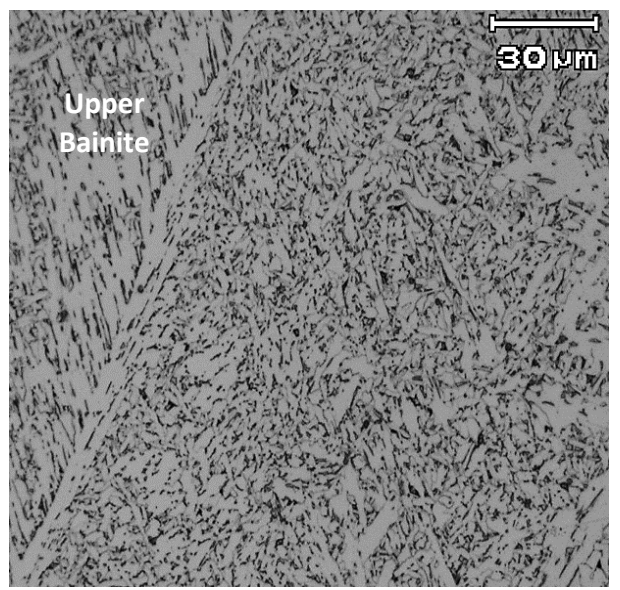

Fig. 5c. Microstructure of Weldment at $0.9 \mathrm{~kJ} / \mathrm{mm}$ of Heat Input. 


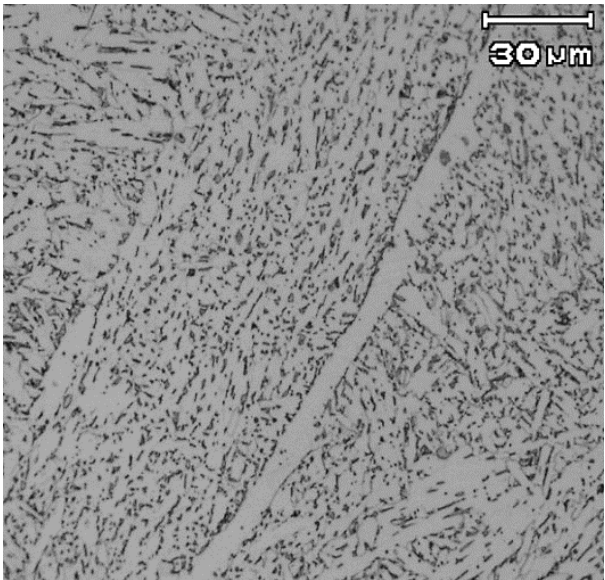

Fig. 5d. Microstructure of Weldment at $1.125 \mathrm{~kJ} / \mathrm{mm}$ of Heat Input.

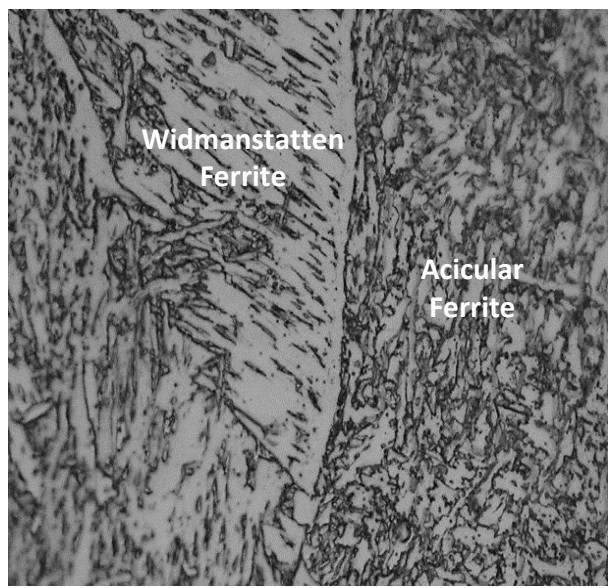

Fig. 5e. Microstructure of Weldment at $1.215 \mathrm{~kJ} / \mathrm{mm}$ of Heat Input.

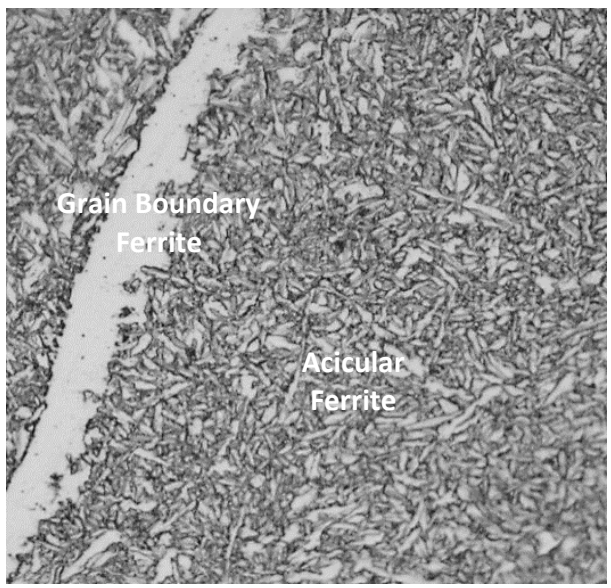

Fig. 5f. Microstructure of Weldment at $1.35 \mathrm{~kJ} / \mathrm{mm}$ of Heat Input.

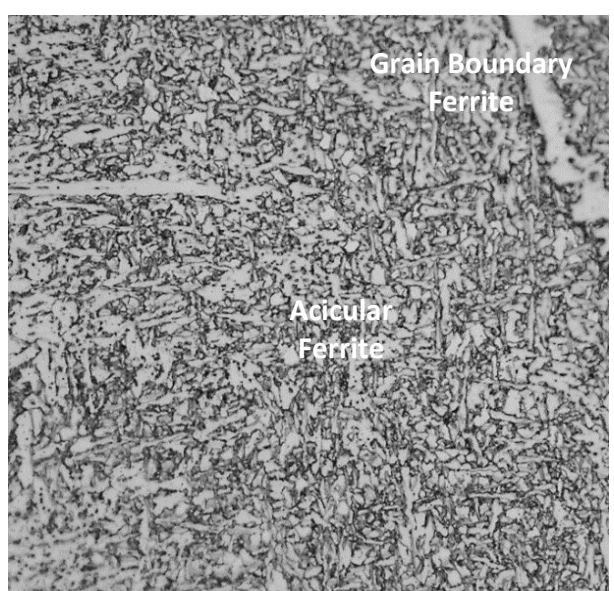

Fig. 5g. Microstructure of Weldment at $1.5 \mathrm{~kJ} / \mathrm{mm}$ of Heat Input.

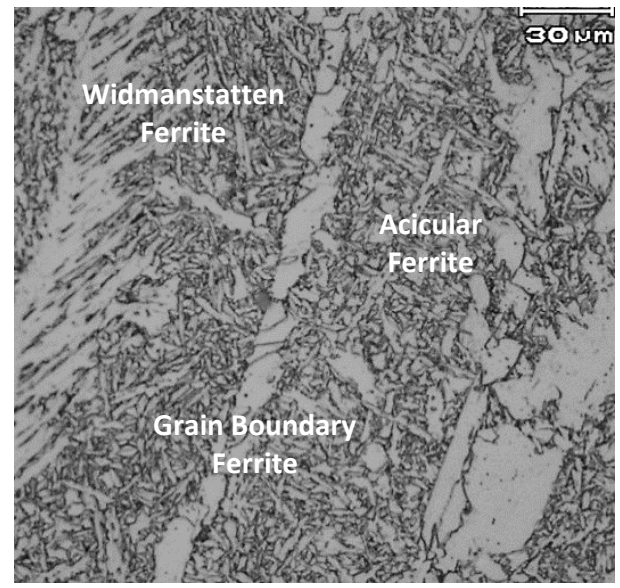

Fig. 5h. Microstructure of Weldment at $1.62 \mathrm{~kJ} / \mathrm{mm}$ of Heat Input.

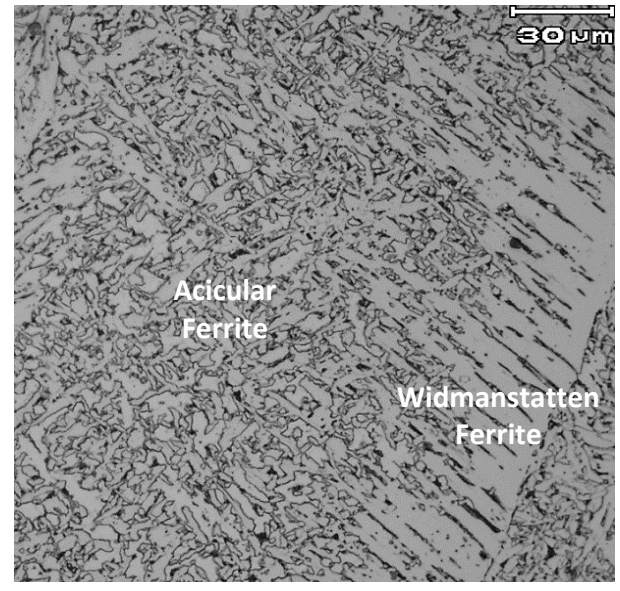

Fig. 5i. Microstructure of Weldment at $1.8 \mathrm{~kJ} / \mathrm{mm}$ of Heat Input. 


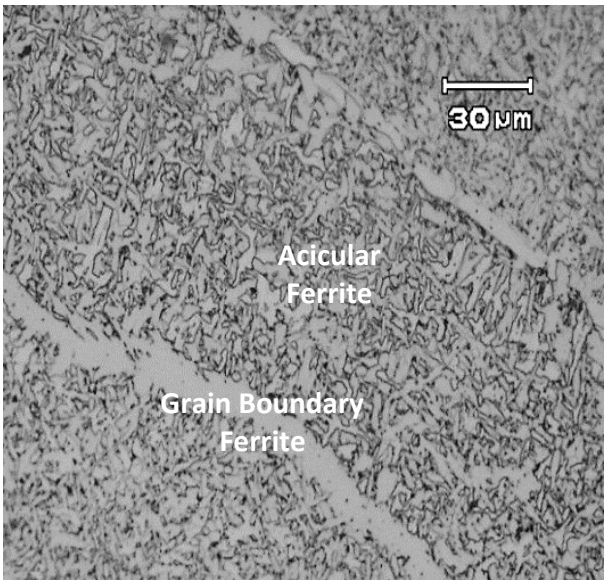

Fig. 5j. Microstructure of Weldment at $1.875 \mathrm{~kJ} / \mathrm{mm}$ of Heat Input.

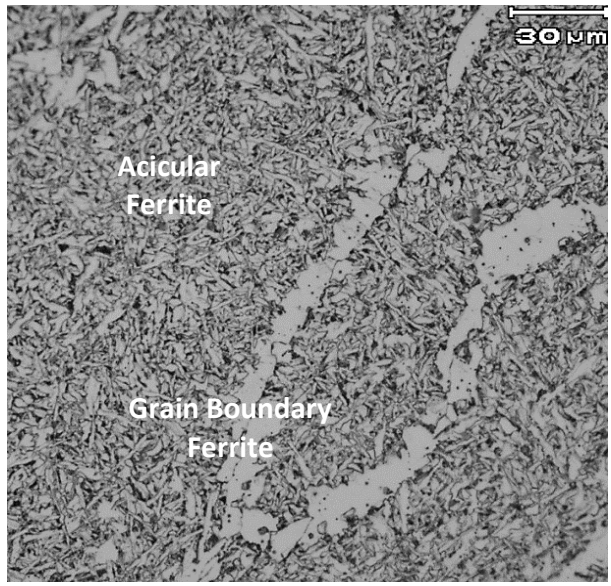

Fig. 5k. Microstructure of Weldment at $2.025 \mathrm{~kJ} / \mathrm{mm}$ of Heat Input.

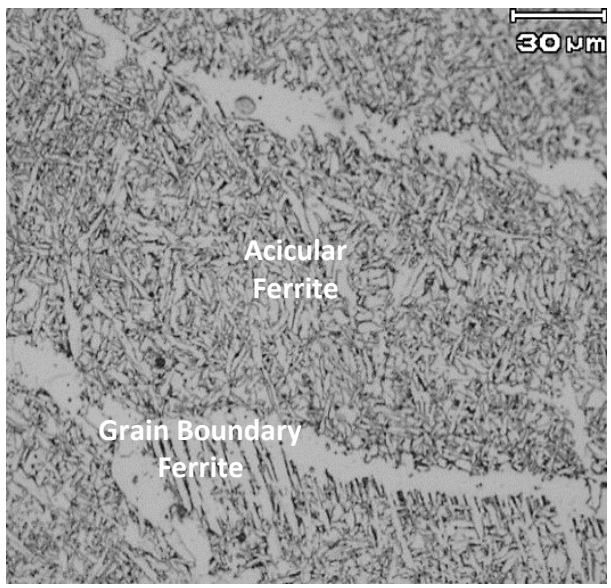

Fig. 5l. Microstructure of Weldment at $2.25 \mathrm{~kJ} / \mathrm{mm}$ of Heat Input.
At the lowest heat input of $0.75 \mathrm{~kJ} / \mathrm{mm}$ the microstructure is formed as lower bainite because at low thermal input causes faster cooling rate so that formed in the form of lower bainite, a long with the increased heat input of the upper bainite formed structure Fig. $5 b-5 d$ because the cooling rate is slower than the $0.75 \mathrm{~kJ} / \mathrm{mm}$ heat input. Increased subsequent heat input from 1.215 $\mathrm{kJ} / \mathrm{mm}$ to $2.25 \mathrm{~kJ} / \mathrm{mm}$ heat input are the dominant increase of acicular ferrite but there are also ferrite grain boundaries and widmanstatten ferrite, this is due to the slower cooling rate, such conditions are shown in Fig. $5 e-51$. The percentage of acicular ferrite structure is seen more and there is a decrease in the percentage of the widmanstatten ferrite structure and the grain boundary ferrite, this condition is caused by a large current strength will increase the heat input thus slowing the corresponding cooling rate for the acicular ferrite formation.

\subsection{Influence of Heat Input on Hardness}

Effect of heat input to the average hardness weld are is shown in Fig. 6 below.

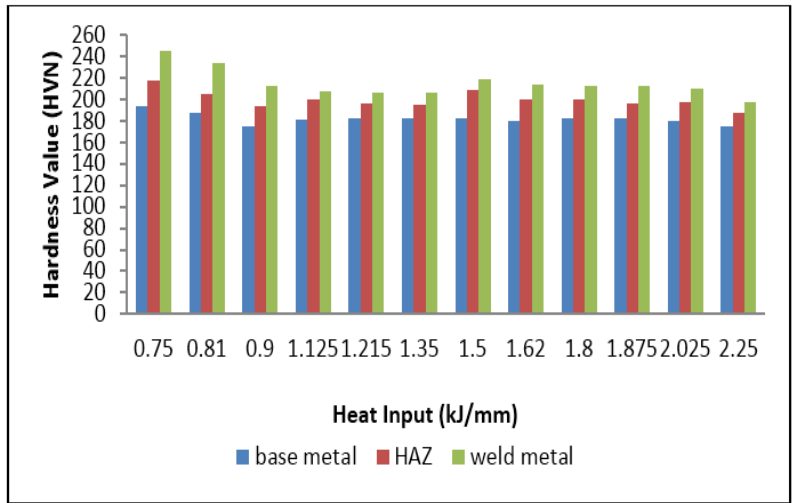

Fig. 6. Influence of Heat Input on Average Hardness at Different Weld Area

Fig. 6 is a bar graphic representation showing the influence of the heat input to the mean hardness values of each of the welded areas including the parent metal, the HAZ region, and the weld metal for various heat input ranging from $0.75 \mathrm{~kJ} / \mathrm{mm}, 25 \mathrm{~kJ} / \mathrm{mm}$. At heat input $0.75 \mathrm{~kJ} / \mathrm{mm}$ has the highest hardness, where the hardness of the parent metal area, HAZ, and welding metal are 194.12 HVN, 217.86 HVN and 244.69 HVN. As for the heat input $2.25 \mathrm{~kJ} / \mathrm{mm}$ has the lowest hardness, where the hardness values are sequentially starting from the parent metal, HAZ, to the welding metal of 174.88 HVN, 187.45 HVN and 197.7 HVN. Tis is due to the low thermal input causing the cooling rate to be fast as well as on the high thermal input, the cooling rate is slow. 


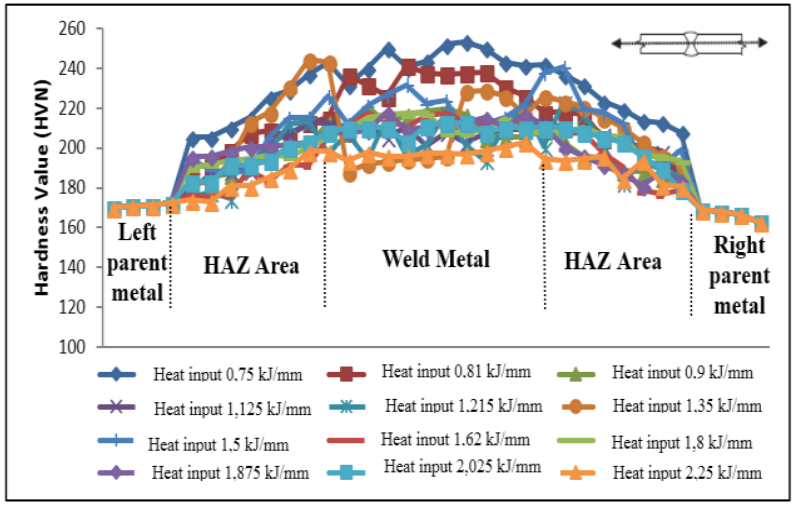

Fig. 7. Micro-Hardness Distribution at different Heat Input at Different Zones

The micro-hardness distribution data in Fig. 7 shows a uniform tendency for each heat input to increase the hardness value of the parent metal to the fine HAZ area then to the coarse HAZ to the welding metal, after which it decreases to the fine HAZ region to the parent metal as a result of cooling rate. This is consistent with the microstructure formed that the coarse HAZ has a bainite structure. Besides, the hardness value does not show the tendency of linear line in the same area. This is because the identified microstructure is not always the same even in one region. In areas of weld metal for example, which have sufficiently random data levels, the identified microstructure of an acicular ferrite, a widmanstatten ferrite or a grain boundary ferrite.

\subsection{Influence of Heat Input on Toughness}

In the following section illustrate the influence of heat input on toughness of API 5L-X65 to determine transition temperature of the overall heat input which can be seen in Fig. 8.

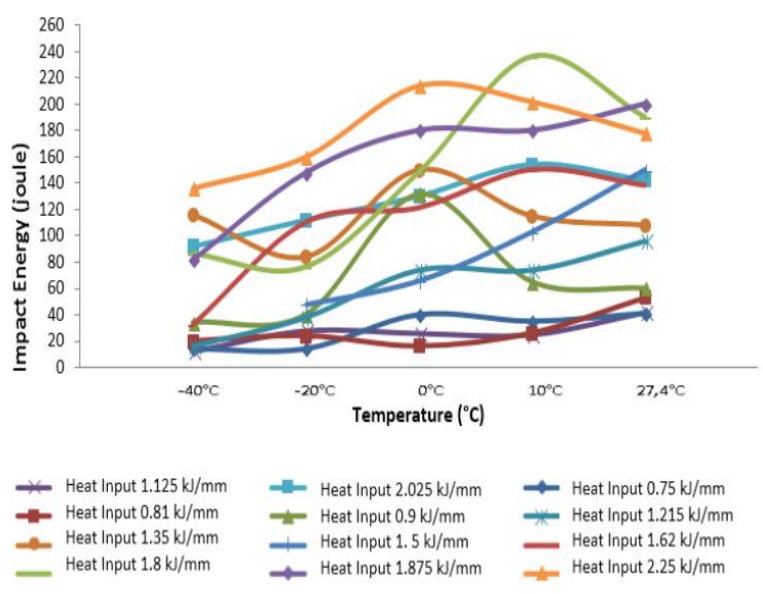

Fig. 8. Toughness at different Heat Input

The transition temperature is the temperature where there is a change in the toughness of the metal from brittle to ductile. The smaller transition temperature lead to the better toughness. The transition temperature at the metal of the welding area by using a heat input of 0.75 $\mathrm{kJ} / \mathrm{mm}, 0.9 \mathrm{~kJ} / \mathrm{mm}, 1.215 \mathrm{~kJ} / \mathrm{mm} .1 .35 \mathrm{~kJ} / \mathrm{mm}$ and 2.25 $\mathrm{kJ} / \mathrm{mm}$ has range $\left(-20^{\circ} \mathrm{C}\right)$ to $0^{\circ} \mathrm{C}$ while in welding with heat input $1.125 \mathrm{~kJ} / \mathrm{mm}, 1.8 \mathrm{~kJ} / \mathrm{mm}$ and $1.875 \mathrm{~kJ} / \mathrm{mm}$ occur in temperature range $\left(-20^{\circ} \mathrm{C}\right)$ to $10^{\circ} \mathrm{C}$ whereas at heat input $0.81 \mathrm{~kJ} / \mathrm{mm}$ and $1.62 \mathrm{~kJ} / \mathrm{mm}$ has range $0^{\circ} \mathrm{C}$ to $10^{\circ} \mathrm{C}$. From these data indicates that the lowest transition temperature occurs in range $\left(-20^{\circ} \mathrm{C}\right)$ to $0^{\circ} \mathrm{C}$ i.e. at $-10^{\circ} \mathrm{C}$ temperatures occurring at a heat input of $0.75 \mathrm{~kJ} / \mathrm{mm}, 0.9$ $\mathrm{kJ} / \mathrm{mm}, 1.215 \mathrm{~kJ} / \mathrm{mm}, 1.35 \mathrm{~kJ} / \mathrm{mm}$ and $2.25 \mathrm{~kJ} / \mathrm{mm}$.

The following sections will explain how the influence of the heat input to the toughness value of the weld metal at a temperature of $-20^{\circ} \mathrm{C}$ is suitable for the application of the electrodes used as welding metal filler. The energy standard at $-20^{\circ} \mathrm{C}$ from the 100 Joule CHWS11 electrode as shown in Table 1.

The toughness value at $-20^{\circ} \mathrm{C}$ has a tendency to increase as heat input increases but fluctuate increasing because in some samples there are defects of incomplete penetration and microhomogenicity of the microstructure on the weld metal where there are some re-infected or reheated zone. The increase in the toughness value that occurs due to the microstructure formed in dominated by acicular ferrites, as described by [6] that acicular ferrite phases are formed intergranularly in the form of short ferrite needles in random directions so that when there is a force from outside the crack fracture that occurs will not quickly propagate because of the interlocking mechanism.

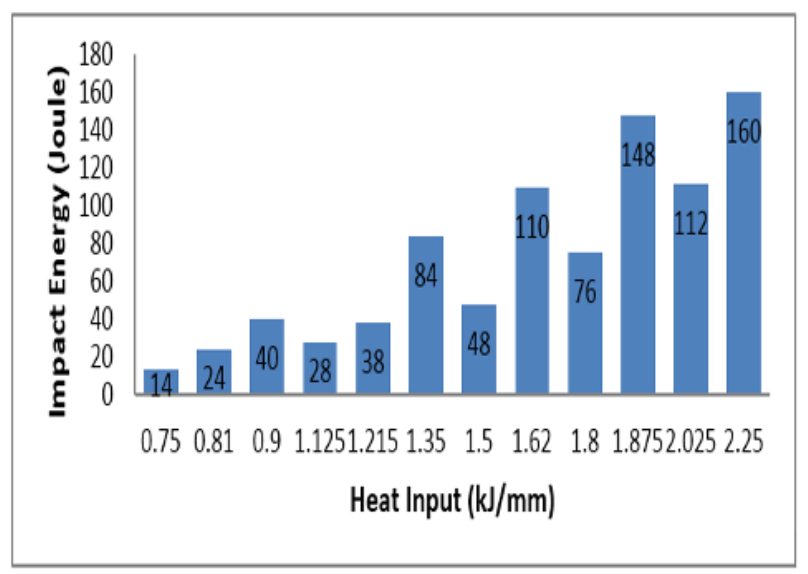

Fig. 9. Influence of Heat Input on Toughness at $-20^{\circ} \mathrm{C}$

In Fig. 9 it is seen that those included in the impact test standard at $-20^{\circ} \mathrm{C}$ are the heat inputs of $1.62 \mathrm{~kJ} / \mathrm{mm}$, $1.875 \mathrm{~kJ} / \mathrm{mm}, 2.025 \mathrm{~kJ} / \mathrm{mm}$ and $2.25 \mathrm{~kJ} / \mathrm{mm}$ respectively totalling 110 joules, 148 joules, 112 joules and 160 joules that have a toughness value above 100 joule so that it complies with applicable standards in the application of API 51-X65 steel welding joints with CHW-S11 filler metal. The highest toughness value occurs at the $2.25 \mathrm{~kJ} / \mathrm{mm}$ heat input which corresponds to the dominant microstructure formed on the weld metal in the form of acicular ferrite phase. 


\section{Conclusions}

After submerged arc welding process, study of microstructural characterization and mechanical properties investigation, following conclusions were drawn:

1. Increasing heat input caused the acicular ferrite phase formed to be more dominant.

2. Increasing heat input caused the grain size at HAZ area was larger, the ranges from 3.76-5.6 mm.

3. The average measured hardness has a maximum value i.e. $244.69 \mathrm{HVN}$ in the $0.75 \mathrm{~kJ} . \mathrm{mm}$ of heat input at weld area and $217.86 \mathrm{HVN}$ at HAZ area.

4. The measured toughness value has an optimum value i.e. 160 joules in the $2.25 \mathrm{~kJ} / \mathrm{mm}$ of heat input at $20^{\circ} \mathrm{C}$ of testing temperature and the ductile-brittle transition temperature was $-10^{\circ} \mathrm{C}$.

\section{References}

1. I. Muda, Teknik Pembentukan Logam I, Teknik Metalurgi Universitas Jenderal Achmad Yani, Bandung (2012).

2. H. Wiryosumarto and T. Okumura, Teknologi Pengelasan Logam, Pradnya Paramita, Jakarta, (2000)

3. R. W. Messler, Principles of Welding Process, Physics, Chemistry \& Metallurgy, John Wiley \& Sons, New York, (1999).

4. R.F. Scott, Key Concept in Welding Engineering, Welding Innovation, vol. XVI No. 1, (1999).

5. D. J. Abson and R. J. Pargeter, Factors Influencing as Deposited Strength, Microstructure and Toughness of Manual Metal Arc Welds Suitable for C-Mn Steel fabrication, International Metals Reviews. Vol 31, pp 141-189, (1986).

6. S. Kou, Welding Metallurgy, John Wiley and Son, New York, 1987. 